\title{
Article \\ Substance Use and Misuse among Adults with Chronic Obstructive Pulmonary Disease in the United States, 2015-2019: Prevalence, Association, and Moderation
}

\author{
Abdullah M. M. Alanazi 1,2,*iD, Mohammed M. Alqahtani 1,2 ${ }^{1}$, Maher M. Alquaimi ${ }^{3}$, Tareq F. Alotaibi 1,2, \\ Saleh S. Algarni 1,2, Taha T. Ismaeil 1,2 ${ }^{\mathbb{D}}$, Ahmad A. Alanazi ${ }^{2,4}$, Moudi M. Alasmari 5,6 Eyas A. Alhuthail 7,8 ${ }^{10}$, \\ Ali M Alasmari ${ }^{9,10}$, Linda Gibson-Young ${ }^{11}$ and Wasantha P. Jayawardene ${ }^{12}$ (D)
}

check for updates

Citation: Alanazi, A.M.M.; Alqahtani, M.M.; Alquaimi, M.M.; Alotaibi, T.F.; Algarni, S.S.; Ismaeil, T.T.; Alanazi, A.A.; Alasmari, M.M.; Alhuthail,

E.A.; Alasmari, A.M.; et al. Substance Use and Misuse among Adults with Chronic Obstructive Pulmonary Disease in the United States, 2015-2019: Prevalence, Association, and Moderation. Int. J. Environ. Res. Public Health 2022, 19, 408. https:// doi.org/10.3390/ijerph19010408

Academic Editor: Carla Berg

Received: 9 November 2021

Accepted: 29 December 2021

Published: 31 December 2021

Publisher's Note: MDPI stays neutral with regard to jurisdictional claims in published maps and institutional affiliations.

Copyright: (c) 2021 by the authors. Licensee MDPI, Basel, Switzerland. This article is an open access article distributed under the terms and conditions of the Creative Commons Attribution (CC BY) license (https:/ / creativecommons.org/licenses/by/ $4.0 /)$.
1 Department of Respiratory Therapy, College of Applied Medical Sciences, King Saud bin Abdulaziz University for Health Sciences, Riyadh 11481, Saudi Arabia; qahtani4@uab.edu (M.M.A.); alotaibita@ksau-hs.edu.sa (T.F.A.); qarnis@ksau-hs.edu.sa (S.S.A.); ismaeilt@ksau-hs.edu.sa (T.T.I.)

2 King Abdullah International Medical Research Center, Riyadh 11481, Saudi Arabia; alanaiziah@ngha.med.sa

3 Department of Respiratory Care, College of Applied Medical Sciences, Imam Abdulrahman Bin Faisal University, Dammam 34212, Saudi Arabia; malquimi@gmail.com

4 Respiratory Services, Ministry of the National Guard-Health Affairs, Riyadh 11481, Saudi Arabia

5 College of Medicine, King Saud bin Abdulaziz University for Health Sciences, Jeddah 22384, Saudi Arabia; asmarim@ksau-hs.edu.sa

6 King Abdullah International Medical Research Center, Jeddah 22384, Saudi Arabia

7 Basic Sciences Department, College of Sciences and Health Professions, King Saud Bin Abdulaziz University for Health Sciences, Riyadh 11481, Saudi Arabia; EXA833@student.bham.ac.uk

8 Department of Biomedical Sciences, Institute of Clinical Sciences, University of Birmingham, Birmingham B15 2TT, UK

9 National Heart and Lung Institute, Imperial College London, London SW7 2BX, UK; a.alasmari18@imperial.ac.uk

10 College of Medical Rehabilitation Sciences, Taibah University, Medina 42353, Saudi Arabia

11 School of Nursing, Auburn University, Auburn, AL 36849, USA; gibsolm@auburn.edu

12 Institute for Research on Addictive Behavior, School of Public Health-Bloomington, Indiana University, Bloomington, IN 47405, USA; wajayawa@indiana.edu

* Correspondence: alanaziab@ksau-hs.edu.sa

Abstract: Background: Despite the advancements in chronic obstructive pulmonary disease (COPD) treatment, complications related to COPD exacerbation remain challenging. One associated factor is substance use/misuse among adults with COPD. Fewer studies, however, examined the prevalence and association between COPD and substance use and misuse. In addition, limited knowledge existed about the moderation effects of serious psychological distress and gender among adults with COPD and substance use/misuse. We aimed, therefore, to measure such prevalence, association, and moderation from nationally representative samples in the United States. Method: Data were drawn from the 2015-2019 National Survey on Drug Use and Health. Weighted logistic regressions were used to measure the associations of last-month tobacco (cigarettes, cigars, pipe, and smokeless tobacco products), other licit and illicit substance use (alcohol, marijuana, cocaine, crack, heroin, hallucinogens, and inhalants), and substance misuse (pain relievers, tranquilizers, stimulants, and sedatives) among adults with COPD. Serious psychological distress and gender were tested as moderators in the association between COPD and substance use/misuse. Results: The findings revealed that adults with COPD [Weighted $N=53,115,718)$ revealed greater odds of cigarettes [adjusted odds ratio $(\mathrm{aOR})=2.48(95 \% \mathrm{CI}=1.80-3.42))$ and smokeless tobacco $(\mathrm{aOR}=3.65(95 \% \mathrm{CI}=1.75-7.65))$. However, they were less likely to use alcohol ( $\mathrm{aOR}=0.61(95 \% \mathrm{CI}=0.45-0.84))$. Adults with COPD who had serious psychological distress were more likely to use pipe tobacco and alcohol; however, they were less likely to use hallucinogens and inhalants. Finally, males compared to females with COPD were less likely to use smokeless tobacco. Conclusion: Adults with COPD in the United States were more likely to use tobacco products and less likely to use alcohol. In addition, serious psychological distress and gender were moderators in associations between COPD and substance use but not in substance misuse. Future studies should longitudinally assess the factors that may contribute to the initiation and progression of substance use and misuse among adults with COPD. 
Keywords: COPD; tobacco products; marijuana; substance use/misuse; serious psychological distress; gender

\section{Introduction}

Chronic obstructive pulmonary disease (COPD) encompasses heterogeneous progressive respiratory disorders that include chronic bronchitis and emphysema [1]. Adults with COPD are presented with airflow limitation and frequent pulmonary complications [2]. Further, the pathophysiology of COPD reveals a variety of contributing factors in the lungs, including parenchymal destruction and narrowing of small airways diseases resulting from chronic inflammations [3,4]. Globally, the pooled prevalence of COPD was $13.1 \%$ where the prevalence of COPD was $6.0 \%$ in the United States $[5,6]$. COPD mortality in the United States has decreased from 2004 to 2018 (72.9 to 67.4 deaths per population of 100,000) [7]; however, significant diversity presents among adults with COPD based on mental health, gender, and risk-taking behaviors [7-9], one of which is smoking that has been documented as the most common risk factor for COPD etiology and exacerbation $[9,10]$.

Smoking cessation is a standard of care for those who are diagnosed with COPD [11]; abstaining from tobacco use, indeed, showed promising health effects in limiting airway obstruction and ameliorating complications associated with COPD [12]. Despite the advancements in care, the associations between tobacco use and COPD remain high [13]. Tobacco use with COPD is not limited to tobacco cigarettes; there are, however, other forms of tobacco use that are observed among adults with COPD that include cigar, pipe, and smokeless tobacco [14-16]. Generally, the concern about substance use with COPD is rising to reduce the health care burden of the complications related to substance use among adults with COPD [17].

Previous studies concluded that substance use increased chronic disease complications, hospitalization, and mortality $[18,19]$. COPD, however, is not an exception, as alcohol, marijuana, and other licit and illicit substances have shown increased inflammatory markers of COPD [20-22]. Similarly, heroin, cocaine, opioids, and stimulants have manifested serious negative outcomes consequently with each use [22-24]. Nevertheless, little is known about the prevalence and association of substance use and adults with COPD in the United States.

COPD is frequently presented with unpleasant psychosensory symptoms of anxiety and pain $[24,25]$. It is unclear whether adults with COPD use non-prescribed substances such as painkillers and tranquilizers to alleviate such manifestations or for other off-label reasons $[24,26,27]$. Nevertheless, the side effects of misusing those substances could lead to catastrophic actions [27-30]. The extent to which adults with COPD use non-prescribed substances remains a concern with uncertainty [31].

Several explanations were proposed to explain the association between chronic diseases and substance use/misuse [32-36], one of which was seeking addictive substances as forms of negative affect avoidance and regulating mood disturbance that were associated with chronic disease manifestation [37,38]. An additional factor was the gender differences among those with COPD [36,39]. Previous research which examined the association between COPD and substance use/misuse accounted for gender differences as a covariate [40-42]; however, it is not clear if gender differences may moderate such association.

Smoking/smokeless tobacco products and substance use/misuse are pervasive among individuals with COPD, but little is known regarding the prevalence and association of substance use/misuse among the adults with COPD at the national level. This study aimed to: (1) evaluate the prevalence of substance use/misuse among adults with COPD; (2) assess the association between COPD and substance use/misuse; and (3) test the serious psychological distress and gender differences as moderators in the association between COPD and substance use/misuse. We hypothesized that the prevalence and association would be stronger among the individual with COPD. Furthermore, we hypothesized that serious psychological distress and gender differences would moderate this association. 


\section{Materials and Methods}

\subsection{Data Source and Sample}

We used five waves of data (2015-2019) from the publicly available National Survey on Drug Use and Health (NSDUH) in the United States [43]. The NSDUH is a crosssectional survey from a nationally and state representative sample of the civilian, noninstitutional US population, ages 12 or older [43]. The original samples consisted of 282,768 respondents; after merging datasets, target participants younger than 18 years were excluded; 67,908 eligible respondents were included in the analysis.

\subsection{Measures}

\subsubsection{COPD Status}

The NSDUH instructed the participants to list each health condition that they may have had during their lifetime. The directed query that assessed COPD "Have you ever been told you had COPD?" was selected. A dichotomous indicator of COPD status was created, with affirmative responses coded as " 1 " and negative responses as " 0 ".

\subsubsection{Substance Use}

Last-month substance use was assessed from the NSDUH's recorded drug use section for tobacco products and other licit and illicit substances. The participants were asked "How long has it been since you last smoked/used [the candidate substance being asked]?" The potential answers were as follows: 1 = within the past 30 days; 2 = more than 30 days ago but within the past 12 months; 3 = more than 12 months ago but within the past 3 years; $4=$ more than 3 years ago; and 91 = never used. Any response that was not " 1 = within the past 30 days" was treated as " $0=$ no." The responses were then binary dichotomized $(0=$ no; $1=$ yes $)$.

The last-month tobacco use was assessed for the following tobacco products: cigarettes, cigars, pipe, and smokeless tobacco. Then, a global variable of "any tobacco use" was created $(0=$ no; $1=$ yes) as an additional category. Any tobacco use refers to the users who consumed any tobacco products (cigarettes, cigars, pipe, and smokeless tobacco) in the last month.

Last-month substance use was assessed as well for the following licit and illicit substance groups: alcohol, marijuana, cocaine, crack, heroin, hallucinogens (LSD, PCP, Psilocybin/Mushrooms, Ecstasy, MDMA, Ketamine, Salvia Divinorum, or any other hallucinogens), and inhalants (not inhaled accidentally, but for kicks or get high). Further, a global variable of "any substance use" was created ( $0=$ no; $1=$ yes) as an additional category. Any substance use refers to the users who consumed any substance that was not tobacco (alcohol, marijuana, cocaine, crack, heroin, hallucinogens, and inhalants) in the last month.

\subsubsection{Substance Misuse}

Last-month substance misuse was defined in NSDUH as "the use in any way not directed by a doctor, including drug diversion; use in greater amounts, more often, or longer than told to take a drug; or use in any other way not directed by a doctor." Misuse of over-the-counter medications was not considered as substance misuse in NSDUH. Lastmonth substance misuse was assessed from the NSDUH's recorded drug use section for the following drug groups: pain relievers, tranquilizers, stimulants, and sedatives. The participants were asked "In the past 30 days, did you use [the candidate substance being asked] in any way a doctor did not direct you to use?" The potential answers were as follows: 1 = yes; 2 = no; 91 = never used $/$ misused pain relievers; and $93=$ did not misuse pain relievers in the past 30 days. Every possible answer that was not $(1=$ yes $)$ was treated as no $(0=$ no). The responses were then binary dichotomized $(0=$ no; $1=$ yes $)$. In addition, a global variable of "any substance misuse" was created $(0=$ no; $1=$ yes $)$ as an additional category. Any substance misuse refers to the users who consumed any non-prescribed medications (pain relievers, tranquilizers, stimulants, and sedatives) in the last month. 


\subsection{Covariates}

\subsubsection{Sociodemographic Characteristics}

Different sociodemographic characteristics were controlled in each model of substance use and misuse. Those covariates were as follows: gender (male, female); age (18-25 years, 26-34 years, 35-49 years, 50-64 years, or $\geq 65$ years); educational attainment (high school or less, high school graduate, some college, associate degree, or college or higher graduate); race (White, Black, Hispanic, Asian, others, or multiracial); and income $(<\$ 20,000$, $\$ 20,000-\$ 49,999, \$ 50,000-\$ 74,999$, or $\$ 75,000$ or more). Sampling year (2015-2019) was controlled as a covariate as well.

\subsubsection{Serious Psychological Distress}

Last-month serious psychological distress $(0=$ no; $1=$ yes $)$ was also considered as a covariate in each analytical model. Last-month serious psychological distress was measured in NSDUH by the validated Kessler Psychological Distress Scale [44].

\subsubsection{Co-Substance Use/Misuse}

To account for the co-substance use/misuse with other substances, any substance use $(0=$ no; $1=$ yes $)$ and any substance misuse $(0=$ no; $1=$ yes $)$ were used in tobacco use models as covariates. Any tobacco product use $(0=$ no; $1=$ yes $)$ and any substance misuse $(0=$ no; $1=$ yes $)$ were used in substance use models as additional covariates. Finally, any tobacco product use $(0=$ no; $1=$ yes $)$ and any substance use $(0=$ no; $1=$ yes $)$ were used in substance misuse models as additional covariates.

\subsection{Statistical Analysis}

In the analytical procedure, COPD was introduced separately with moderators and covariates in each model as the independent variables. The dependent variables were each substance use/misuse. Each model was tested as the following example:

Last-month cigarette use $=\mathrm{COPD} \times(\mathrm{COPD} \times$ serious psychological distress $)$

$\times(\mathrm{COPD} \times$ gender $) \times$ covariates $($ serious psychological distress, gender, age, race, educational attainment, and income).

Frequencies were generated to assess the prevalence of last-month substance use/misuse among adults with COPD. Chi-square tests of independence were used for the comparisons between sample characteristics among adults with and without COPD. Bivariate analyses were generated using unadjusted logistic regression for the comparisons of all substance use/misuse in COPD versus non-COPD groups. Next, adjusted logistic regressions were used to assess the association between adults with COPD and substance use/misuse besides testing the moderation effects of last-month serious psychological distress $(0=$ no; 1 = yes $)$ and gender differences $(0=$ females; $1=$ males $)$ in the association between COPD and substance use/misuse. The two moderators were introduced in the models that were "COPD $(1=$ yes $) X$ serious psychological distress $(1=$ yes $)$ " and COPD "( $1=$ yes $)$ X Gender $(1=$ males $) . "$ All analyses were conducted in STATA/SE 17.0 and accounted for the complex survey design weights by the NSDUH by the strata and clusters provided, as well as adjusting the analytical weights to account for five years (2015-2019).

\section{Results}

\section{Sample Characteristics}

Sociodemographic data of the adults with COPD (weighted $N=53,115,718$ ) and those without COPD (weighted $N=456,191,448$ ) are shown in Table 1 . In both groups, most respondents were females and whites. Older respondents, lower status of educational attainments, lower income, and greater serious psychological distress were more prevalent in the COPD group than those without COPD. Table 2 presents the prevalence of last-month substance use/misuse among both groups. Compared to those without COPD, adults with 
COPD reported significantly higher prevalence of cigarette and pipe tobacco products, except for smokeless tobacco. Moreover, they had significantly greater use of marijuana and less use of alcohol. Finally, adults with COPD reported significantly greater use of any tobacco products and any substance misuse; however, they reported less use of any substance that was not tobacco.

Table 1. Weighted sociodemographic characteristics of adults with COPD.

\begin{tabular}{|c|c|c|c|}
\hline Variable & COPD $=$ No & COPD = Yes & $x^{2}$ \\
\hline Weighted $N$ & $456,191,448$ & $53,115,718$ & ( $p$ Value) \\
\hline $\begin{array}{l}\text { Gender } \\
\text { Male } \\
\text { Female }\end{array}$ & $\begin{array}{l}44.4 \% \\
55.6 \% \\
\end{array}$ & $\begin{array}{l}36.8 \% \\
63.2 \% \\
\end{array}$ & $\begin{array}{c}134.2 \\
(p<0.001)\end{array}$ \\
\hline $\begin{array}{c}\text { Age } \\
18-25 \text { years } \\
26-34 \text { years } \\
35-49 \text { years } \\
50-64 \text { years } \\
\geq 65 \text { years }\end{array}$ & $\begin{array}{l}20.7 \% \\
14.6 \% \\
26.6 \% \\
18.7 \% \\
19.3 \%\end{array}$ & $\begin{array}{l}11.0 \% \\
10.0 \% \\
25.2 \% \\
25.0 \% \\
28.8 \%\end{array}$ & $\begin{array}{c}723.2 \\
(p<0.001)\end{array}$ \\
\hline $\begin{array}{c}\text { Educational attainment } \\
\text { High school or less } \\
\text { High school graduate } \\
\text { Some college } \\
\text { Associate degree } \\
\text { College or higher graduate }\end{array}$ & $\begin{array}{l}11.9 \% \\
25.6 \% \\
24.0 \% \\
10.2 \% \\
28.3 \%\end{array}$ & $\begin{array}{c}11.9 \% \\
31.3 \% \\
25.9 \% \\
9.5 \% \\
17.1 \% \\
\end{array}$ & $\begin{array}{c}490.2 \\
(p<0.001)\end{array}$ \\
\hline $\begin{array}{l}\text { Race } \\
\text { White } \\
\text { Black } \\
\text { Hispanic } \\
\text { Asian } \\
\text { Others } \\
\text { Multiracial }\end{array}$ & $\begin{array}{l}64.4 \% \\
13.6 \% \\
13.1 \% \\
3.5 \% \\
1.8 \% \\
3.6 \%\end{array}$ & $\begin{array}{c}74.7 \% \\
9.3 \% \\
8.1 \% \\
1.2 \% \\
1.9 \% \\
4.8 \%\end{array}$ & $\begin{array}{c}391.7 \\
(p<0.001)\end{array}$ \\
\hline $\begin{array}{c}\text { Income } \\
<\$ 20,000 \\
\$ 20,000-\$ 49,999 \\
\$ 50,000-\$ 74,999 \\
\geq \$ 75,000\end{array}$ & $\begin{array}{l}19.3 \% \\
30.9 \% \\
16.1 \% \\
33.7 \%\end{array}$ & $\begin{array}{l}28.7 \% \\
36.0 \% \\
14.5 \% \\
20.8 \%\end{array}$ & $\begin{array}{c}587.8 \\
(p<0.001)\end{array}$ \\
\hline $\begin{array}{c}\text { Last-month serious } \\
\text { psychological distress } \\
\text { No } \\
\text { Yes }\end{array}$ & $\begin{array}{c}91.0 \% \\
9.0 \%\end{array}$ & $\begin{array}{l}84.5 \% \\
15.5 \%\end{array}$ & $\begin{array}{c}279.4 \\
(p<0.001)\end{array}$ \\
\hline
\end{tabular}


Table 2. Weighted prevalence of last-month substance use and misuse among adults with COPD.

\begin{tabular}{|c|c|c|c|}
\hline Substances & $\mathrm{COPD}=\mathrm{No}$ & COPD = Yes & $\begin{array}{c}\text { OR } \\
(95 \% \mathrm{CI})\end{array}$ \\
\hline Tobacco Cigarettes & $31.2 \%$ & $48.7 \%$ & $\begin{array}{c}2.08 \\
(1.96-2.21)\end{array}$ \\
\hline Tobacco Cigars & $14.5 \%$ & $15.6 \%$ & $\begin{array}{c}1.08 \\
(0.97-1.22)\end{array}$ \\
\hline Pipe Tobacco & $7.0 \%$ & $8.8 \%$ & $\begin{array}{c}1.28 \\
(1.03-1.58)\end{array}$ \\
\hline Smokeless Tobacco & $20.1 \%$ & $16.3 \%$ & $\begin{array}{c}0.77 \\
(0.66-0.90)\end{array}$ \\
\hline Alcohol & $61.5 \%$ & $49.2 \%$ & $\begin{array}{c}0.60 \\
(0.57-0.64)\end{array}$ \\
\hline Marijuana & $21.7 \%$ & $23.2 \%$ & $\begin{array}{c}1.09 \\
(1.01-1.18)\end{array}$ \\
\hline Cocaine & $4.7 \%$ & $4.0 \%$ & $\begin{array}{c}0.83 \\
(0.63-1.10)\end{array}$ \\
\hline Crack & $4.2 \%$ & $4.5 \%$ & $\begin{array}{c}1.07 \\
(0.69-1.68)\end{array}$ \\
\hline Heroin & $9.0 \%$ & $7.6 \%$ & $\begin{array}{c}0.82 \\
(0.52-1.29)\end{array}$ \\
\hline Hallucinogens & $3.1 \%$ & $2.5 \%$ & $\begin{array}{c}0.79 \\
(0.57-1.11)\end{array}$ \\
\hline Inhalants & $2.2 \%$ & $1.3 \%$ & $\begin{array}{c}0.62 \\
(0.34-1.12)\end{array}$ \\
\hline Non-prescribed Pain Relievers & $12.7 \%$ & $13.7 \%$ & $\begin{array}{c}1.09 \\
(0.90-1.31)\end{array}$ \\
\hline Non-prescribed Tranquilizers & $15.6 \%$ & $16.7 \%$ & $\begin{array}{c}1.08 \\
(0.84-1.38)\end{array}$ \\
\hline Non-prescribed Stimulants & $14.7 \%$ & $13.1 \%$ & $\begin{array}{c}0.87 \\
(0.64-1.19)\end{array}$ \\
\hline Non-prescribed Sedatives & $7.5 \%$ & $5.4 \%$ & $\begin{array}{c}0.71 \\
(0.42-1.19)\end{array}$ \\
\hline Any tobacco use & $39.8 \%$ & $54.9 \%$ & $\begin{array}{c}1.84 \\
(1.73-1.95)\end{array}$ \\
\hline Any substance use & $64.1 \%$ & $45.5 \%$ & $\begin{array}{c}0.67 \\
(0.63-0.71)\end{array}$ \\
\hline Any substance misuse & $21.7 \%$ & $24.6 \%$ & $\begin{array}{c}1.17 \\
(1.02-1.34)\end{array}$ \\
\hline
\end{tabular}

Table 3 depicts the odds of last-month substance use/misuse among adults with COPD. Accounting for covariates, those with COPD were more likely to use cigarettes $(\mathrm{aOR}=2.48(95 \% \mathrm{CI}=1.80-3.42))$, smokeless tobacco $(\mathrm{aOR}=3.65(95 \% \mathrm{CI}=1.75-7.65))$, and use any tobacco products $(\mathrm{aOR}=2.57(95 \% \mathrm{CI}=1.91-3.48))$. However, they were less likely to use alcohol $(\mathrm{aOR}=0.61(95 \% \mathrm{CI}=0.45-0.84))$ and use any substance that was not tobacco $(\mathrm{aOR}=0.69(95 \% \mathrm{CI}=0.51-0.93))$. 
Table 3. The association between adults with COPD and last-month substance use/misuse.

\begin{tabular}{|c|c|c|c|}
\hline \multirow[b]{2}{*}{ Dependent Variables } & \multicolumn{3}{|c|}{ Independent Variables } \\
\hline & COPD & $\begin{array}{c}\text { COPD X Serious } \\
\text { Psychological Distress }\end{array}$ & COPD X Gender \\
\hline Tobacco cigarettes & $2.48[1.80-3.42]$ & $1.17[0.73-1.88]$ & $0.78[0.49-1.24]$ \\
\hline Tobacco cigars & $1.29[0.77-2.15]$ & $0.95[0.55-1.63]$ & $0.83[0.55-1.63]$ \\
\hline Pipe tobacco & $1.08[0.36-3.22]$ & 3.85 [1.46-10.13] & $1.02[0.37-2.80]$ \\
\hline Smokeless tobacco & $3.65[1.75-7.65]$ & 0.61 [0.27-1.39] & $0.23[0.10-0.50]$ \\
\hline Alcohol & $0.61[0.45-0.84]$ & $1.64[1.04-2.58]$ & $1.01[0.62-1.60]$ \\
\hline Marijuana & $1.11[0.81-1.51]$ & 1.14 [0.72-1.79] & 1.01 [0.65-1.55] \\
\hline Cocaine & $0.97[0.44-2.13]$ & $0.57[0.18-1.83]$ & $0.62[0.31-1.22]$ \\
\hline Crack & $0.47[0.13-1.62]$ & 2.32 [0.49-10.91] & 0.25 [0.04-1.33] \\
\hline Heroin & $0.69[0.26-1.82]$ & $1.01[0.29-3.40]$ & 1.08 [0.33-3.52] \\
\hline Hallucinogens & $0.98[0.51-1.87]$ & $0.26[0.08-0.81]$ & 1.66 [0.57-4.83] \\
\hline Inhalants & $1.28[0.32-5.03]$ & $0.14[0.02-0.74]$ & $1.33[0.29-6.16]$ \\
\hline $\begin{array}{l}\text { Non-prescribed } \\
\text { pain relievers }\end{array}$ & $0.72[0.42-1.24]$ & $0.92[0.44-1.92]$ & $1.36[0.78-2.38]$ \\
\hline $\begin{array}{l}\text { Non-prescribed } \\
\text { tranquilizers }\end{array}$ & $1.08[0.55-2.11]$ & $1.27[0.57-2.85]$ & $0.83[0.37-1.83]$ \\
\hline $\begin{array}{l}\text { Non-prescribed } \\
\text { stimulants }\end{array}$ & $0.75[0.33-1.70]$ & $1.39[0.58-3.30]$ & $0.73[0.31-1.71]$ \\
\hline $\begin{array}{l}\text { Non-prescribed } \\
\text { sedatives }\end{array}$ & $0.42[0.15-1.15]$ & $0.92[0.20-4.24]$ & 2.84 [0.59-13.49] \\
\hline Any tobacco use & $2.57[1.91-3.48]$ & $1.10[0.70-1.71]$ & $0.54[0.34-0.85]$ \\
\hline Any substance use & $0.69[0.51-0.93]$ & $1.51[0.90-2.52]$ & $1.06[0.66-1.69]$ \\
\hline Any substance misuse & 1.09 [0.77-1.55] & $0.82[0.52-1.28]$ & $1.48[0.94-2.35]$ \\
\hline
\end{tabular}

Adjusted Odds Ratios of last-month substance use/misuse among adults with COPD. All models were controlled for gender, age, educational attainment, race, income, last-month serious psychological distress, and sampling year.

To test the hypothesis that serious psychological distress and gender moderated the association between adults with COPD and substance use/misuse, these moderators were also reported in Table 3. Adults with COPD who have reported serious psychological distress in the last month were more likely to use pipe tobacco $(\mathrm{aOR}=3.85$ $(95 \% \mathrm{CI}=1.46-10.13))$ and alcohol $(\mathrm{aOR}=1.64(95 \% \mathrm{CI}=1.04-2.58))$. However, they were less likely to use hallucinogens $(\mathrm{aOR}=0.26(95 \% \mathrm{CI}=0.08-0.81))$ and inhalants $(\mathrm{aOR}=0.14(95 \% \mathrm{CI}=0.02-0.74))$. Similarly, adults with COPD and reported their gender as males were less likely to use smokeless tobacco $(\mathrm{aOR}=0.23(95 \% \mathrm{CI}=0.10-0.50))$ and any tobacco products $(\mathrm{aOR}=0.54(95 \% \mathrm{CI}=0.34-0.85))$.

\section{Discussion}

This study assessed the prevalence and association of substance use/misuse among adults with COPD and whether serious psychological distress and gender differences moderated this association from nationally representative samples in the United States (2015-2019). The findings revealed that last-month use of tobacco cigarettes and smokeless tobacco were more likely among adults with COPD. However, those with COPD were less likely to use alcohol in the last month. Moreover, adults with COPD who had serious psychological distress in the last month were more likely to use pipe tobacco and alcohol in the last month. However, they were less likely to use hallucinogens and inhalants in the last month. Finally, male adults who have COPD were less likely to use smokeless tobacco in the last month.

The harmful impact of tobacco smoking is not limited merely to the onset of COPD [30] but accelerates the process of cell senescence, which decreases proliferation with preserved metabolic activity, contributing to increased inflammation, reduced cell regeneration, and 
carcinogenesis [45]. Similarly, smokeless tobacco product use poses an additional risk for COPD $[16,46]$. The dual use of smokeless and smoked tobacco is linked with an increased risk of cardiovascular disease, cancer, and mortality [16,47-49]. This suggests that smoking cessation should be capitalized on both forms of tobacco use among adults with COPD.

As a result of the chronicity and dependency of tobacco use, smoking cessation is extremely hard for those with COPD despite the health benefits of quitting [50,51]. The attachment to tobacco use is attributed to many factors, from social pressure to the inability to deal with triggers and cravings, and as an escape mechanism from negative affect [38,52-54]. A holistic smoking cessation approach should be emphasized in adults with COPD from pharmacological agents to behavioral support and psychosocial screening and prevention to optimize their treatment plans.

This study revealed, moreover, that adults with COPD were less likely to use alcohol in the last month. Alternatively, the study findings depicted those adults with COPD who selfreported serious psychological distress were more likely to use alcohol in the last month, which may explain that those who have COPD and experienced serious psychological distress may seek alternative mood regulator substances, such as alcohol [55]. Although alcohol use disorder is not directly associated with the onset of COPD, alcohol use disorder was associated with increased morbidity and health care utilizations among adults with COPD in the United States, which signified its impact with pulmonary diseases [56].

Generally, chronic health conditions were associated with a higher likelihood of any substance use and being more likely to be hospitalized for chronic health conditions [18]. Those with COPD in this study, however, reported significantly less use of any substance that was not tobacco than those without COPD [18,57]. It is warranted, therefore, to consider individual differences, such as serious psychological distress and gender, that may increase or decrease substance use/misuse among adults with COPD to optimize treatment and prevention services that ultimately improve health outcomes.

This study has some limitations. First, the sampling did not include homeless and active military people. Second, the design of the NSDUH is cross-sectional; hence, we cannot determine the temporality between COPD symptomology and substance use/misuse. Third, the clinical manifestations of COPD usually present at older ages; however, it was found in the NSDUH samples that some individuals who self-reported COPD were at younger ages (18-25 years), which threatened the accuracy of self-reported COPD in the samples. Finally, NSDUH samples did not ask about electronic cigarettes or vaping to assess new trends of emerging tobacco products among adults with COPD.

\section{Conclusions}

This study provided a better understanding of the prevalence, association, and moderation between adults with COPD and substance use/misuse in the United States. In general, adults with COPD were more likely to use tobacco cigarettes and smokeless tobacco. However, they were less likely to use alcohol. This study invokes the necessity of conducting longitudinal studies to determine the triggering factors and causal relationships more definitively between COPD diagnosis and substance use/misuse among adults to better design treatment intervention and prevention programs.

Author Contributions: A.M.M.A., the Principal Investigator of the current research study and developed the study concept. A.M.M.A., M.M.A. (Mohammed M. Alqahtani), M.M.A. (Maher M. Alquaimi), T.F.A., S.S.A., T.T.I., A.A.A., M.M.A. (Moudi M. Alasmari), E.A.A., A.M.A., L.G.-Y., and W.P.J. drafted and revised the manuscript. All authors have read and agreed to the published version of the manuscript.

Funding: This research received no external funding.

Institutional Review Board Statement: Not applicable.

Informed Consent Statement: Not applicable. 
Data Availability Statement: Publicly available datasets were analyzed in this study. This data can be found here: [https: / www.samhsa.gov/data/data-we-collect/nsduh-national-survey-drug-useand-health] (accessed on 9 November 2021).

Conflicts of Interest: The authors declare no conflict of interest.

\section{References}

1. Vestbo, J.; Hurd, S.S.; Agustí, A.G.; Jones, P.W.; Vogelmeier, C.; Anzueto, A.; Barnes, P.J.; Fabbri, L.M.; Martinez, F.J.; Nishimura, M. Global strategy for the diagnosis, management, and prevention of chronic obstructive pulmonary disease: GOLD executive summary. Am. J. Res. Crit. Care Med. 2013, 187, 347-365. [CrossRef] [PubMed]

2. Macklem, P. Therapeutic implications of the pathophysiology of COPD. Eur. Respir. J. 2010, 35, 676-680. [CrossRef] [PubMed]

3. MacNee, W. Pathology, pathogenesis, and pathophysiology. BMJ 2006, 332, 1202-1204. [CrossRef]

4. Hogg, J.C.; Timens, W. The pathology of chronic obstructive pulmonary disease. Ann. Rev. Pathol. Mechan. Dis. 2009, 4, 435-459. [CrossRef]

5. Blanco, I.; Diego, I.; Bueno, P.; Casas-Maldonado, F.; Miravitlles, M. Geographic distribution of COPD prevalence in the world displayed by Geographic Information System maps. Eur. Res. J. 2019, 54. [CrossRef]

6. Biener, A.I.; Decker, S.L.; Rohde, F. Prevalence and treatment of chronic obstructive pulmonary disease (COPD) in the United States. JAMA 2019, 322, 602. [CrossRef]

7. Zarrabian, B.; Mirsaeidi, M. A Trend Analysis of Chronic Obstructive Pulmonary Disease Mortality in the United States by Race and Sex. Ann. Am. Thor. Soc. 2021, 18, 1138-1146. [CrossRef]

8. Tselebis, A.; Pachi, A.; Ilias, I.; Kosmas, E.; Bratis, D.; Moussas, G.; Tzanakis, N. Strategies to improve anxiety and depression in patients with COPD: A mental health perspective. Neuropsych. Dis. Treat. 2016, 12, 297-328. [CrossRef]

9. Zhao, Q.; Meng, M.; Kumar, R.; Wu, Y.; Huang, J.; Lian, N.; Deng, Y.; Lin, S. The impact of COPD and smoking history on the severity of COVID-19: A systemic review and meta-analysis. J. Med. Virol. 2020, 92, 1915-1921. [CrossRef]

10. Agustí, A.; Faner, R. COPD beyond smoking: New paradigm, novel opportunities. Lancet Res. Med. 2018, 6, 324-326. [CrossRef]

11. Strassmann, R.; Bausch, B.; Spaar, A.; Kleijnen, J.; Braendli, O.; Puhan, M.A. Smoking cessation interventions in COPD: A network meta-analysis of randomised trials. Eur. Res. J. 2009, 34, 634-640. [CrossRef]

12. Godtfredsen, N.S.; Lam, T.H.; Hansel, T.T.; Leon, M.; Gray, N.; Dresler, C.; Burns, D.; Prescott, E.; Vestbo, J. COPD-related morbidity and mortality after smoking cessation: Status of the evidence. Eur. Res. J. 2008, 32, 844-853. [CrossRef]

13. Wheaton, A.G.; Liu, Y.; Croft, J.B.; VanFrank, B.; Croxton, T.L.; Punturieri, A.; Postow, L.; Greenlund, K.J. Chronic obstructive pulmonary disease and smoking status-United States, 2017. Morb. Mortal. Week Rep. 2019, 68, 533. [CrossRef] [PubMed]

14. Chang, C.M.; Corey, C.G.; Rostron, B.L.; Apelberg, B.J. Systematic review of cigar smoking and all cause and smoking related mortality. BMC Public Health 2015, 15, 390. [CrossRef]

15. Bahtouee, M.; Maleki, N.; Nekouee, F. The prevalence of chronic obstructive pulmonary disease in hookah smokers. Chron. Res. Dis. 2018, 15, 165-172. [CrossRef] [PubMed]

16. Henley, S.J.; Connell, C.J.; Richter, P.; Husten, C.; Pechacek, T.; Calle, E.E.; Thun, M.J. Tobacco-related disease mortality among men who switched from cigarettes to spit tobacco. Tobac. Control 2007, 16, 22-28. [CrossRef]

17. Salman, S.; Asghar, S.; Usman, M.; Anees, M.; Idrees, J.; Shah, F.H.; Nauman, Z.; Rubya, K.; Bibi, H. Substance use disorder, lung cancer, and COPD. Res. Med. 2017, 132, 278-279. [CrossRef]

18. Wu, L.-T.; Zhu, H.; Ghitza, U.E. Multicomorbidity of chronic diseases and substance use disorders and their association with hospitalization: Results from electronic health records data. Drug Alcohol. Depend. 2018, 192, 316-323. [CrossRef]

19. Seth, P.; Scholl, L.; Rudd, R.A.; Bacon, S. Overdose deaths involving opioids, cocaine, and psychostimulants-United States, 2015-2016. Morb. Mortal. Wkly. Rep. 2018, 67, 349. [CrossRef] [PubMed]

20. Helyes, Z.; Kemény, Á.; Csekő, K.; Szőke, É.; Elekes, K.; Mester, M.; Sándor, K.; Perkecz, A.; Kereskai, L.; Mark, L. Marijuana smoke induces severe pulmonary hyperresponsiveness, inflammation, and emphysema in a predictive mouse model not via CB1 receptor activation. Am. J. Physiol. Lung Cellul. Mol. Physiol. 2017, 313, L267-L277. [CrossRef] [PubMed]

21. Mehta, A.J.; Guidot, D.M. Alcohol and the lung. Alcohol Res. Curr. Rev. 2017, 38, 243.

22. Mehta, S.; Parmar, N.; Kelleher, M.; Jolley, C.J.; White, P.; Durbaba, S.; Ashworth, M. COPD and asthma in patients with opioid dependency: A cross-sectional study in primary care. NPJ Prim. Care Respir. Med. 2020, 30, 4. [CrossRef]

23. Bond, M.C.; Butler, K.H.; Richardson, A.C.; Blosser, K.M. Chest imaging of hypersensitivity pneumonitis induced by heroin abuse. Clin. Case Rep. 2021, 9, e04366. [CrossRef]

24. Lee, A.L.; Goldstein, R.S.; Brooks, D. Chronic pain in people with chronic obstructive pulmonary disease: Prevalence, clinical and psychological implications. Chron. Obstruct. Pulmon. Dis. 2017, 4, 194. [CrossRef] [PubMed]

25. Thakur, E.R.; Sansgiry, S.; Petersen, N.J.; Stanley, M.; Kunik, M.E.; Naik, A.D.; Cully, J.A. Cognitive and perceptual factors, not disease severity, are linked with anxiety in COPD: Results from a cross-sectional study. Int. J. Behav. Med. 2018, 25, 74-84. [CrossRef]

26. Viglino, D.; Daoust, R.; Bailly, S.; Faivre-Pierret, C.; Charif, I.; Roustit, M.; Paquet, J.; Debaty, G.; Pépin, J.-L.; Maignan, M. Opioid drug use in emergency and adverse outcomes among patients with chronic obstructive pulmonary disease: A multicenter observational study. Sci. Rep. 2020, 10, 5038. [CrossRef] 
27. Macmurdo, M.; Lopez, R.; Udeh, B.; Zein, J. Beyond tobacco-the secondary impact of substance misuse in chronic obstructive lung disease. J. Asthma 2020, 1-12. [CrossRef]

28. George, C.F.; Bayliff, C.D. Management of insomnia in patients with chronic obstructive pulmonary disease. Drugs 2003, 63, 379-387. [CrossRef] [PubMed]

29. Rodriguez-Roisin, R.; Garcia-Aymerich, J. Should we exercise caution with benzodiazepine use in patients with COPD? Eur. Respir. Soc. 2014, 44, 284-286. [CrossRef]

30. Stege, G.; Vos, P.J.; van den Elshout, F.J.; Dekhuijzen, P.R.; van de Ven, M.J.; Heijdra, Y.F. Sleep, hypnotics and chronic obstructive pulmonary disease. Respir. Med. 2008, 102, 801-814. [CrossRef]

31. Hulin, J.; Brodie, A.; Stevens, J.; Mitchell, C. Prevalence of respiratory conditions among people who use illicit opioids: A systematic review. Addiction 2020, 115, 832-849. [CrossRef]

32. Stellefson, M.; Wang, M.-Q.; Kinder, C. Racial Disparities in Health Risk Indicators Reported by Alabamians Diagnosed with COPD. Int. J. Environ. Res. Public Health 2021, 18, 9662. [CrossRef]

33. DiSilvio, B.; Baqdunes, M.; Alhajhusain, A.; Cheema, T. Smoking addiction and strategies for cessation. Crit. Care Nurs. Quart. 2021, 44, 33-48. [CrossRef]

34. Stellefson, M.; Wang, M.Q.; Balanay, J.A.G.; Wu, R.; Paige, S.R. Latent Health Risk Classes Associated with Poor Physical and Mental Outcomes in Workers with COPD from Central Appalachian US States. Int. J. Environ. Res. Public Health 2020, 17, 6798. [CrossRef] [PubMed]

35. Koslik, H.J.; Joshua, J.; Cuevas-Mota, J.; Goba, D.; Oren, E.; Alcaraz, J.E.; Garfein, R.S. Prevalence and correlates of obstructive lung disease among people who inject drugs, San Diego, California. Drug Alcohol. Depend. 2020, 214, 108158. [CrossRef] [PubMed]

36. Bade, B.C.; DeRycke, E.C.; Ramsey, C.; Skanderson, M.; Crothers, K.; Haskell, S.; Bean-Mayberry, B.; Brandt, C.; Bastian, L.A.; Akgün, K.M. Sex differences in veterans admitted to the hospital for chronic obstructive pulmonary disease exacerbation. Ann. Am. Thorac. Soc. 2019, 16, 707-714. [CrossRef]

37. Alqahtani, M.M.; Alanazi, A.M.; Pavela, G.; Dransfield, M.T.; Wells, J.M.; Lein, D.H.; Hendricks, P.S. Binge Drinking Moderates the Association Between Chronic Lung Disease and E-Cigarette Use. Respir. Care 2021, 66, 936-942. [CrossRef]

38. Baker, T.B.; Piper, M.E.; McCarthy, D.E.; Majeskie, M.R.; Fiore, M.C. Addiction motivation reformulated: An affective processing model of negative reinforcement. Psychol. Rev. 2004, 111, 33-51. [CrossRef] [PubMed]

39. Jain, N.; Thakkar, M.; Jain, N.; Rohan, K.; Sharma, M. Chronic obstructive pulmonary disease: Does gender really matter? Lung India Off. Organ Ind. Chest Soc. 2011, 28, 258.

40. Carmona-Pírez, J.; Poblador-Plou, B.; Ioakeim-Skoufa, I.; González-Rubio, F.; Gimeno-Feliú, L.A.; Díez-Manglano, J.; LagunaBerna, C.; Marin, J.M.; Gimeno-Miguel, A.; Prados-Torres, A. Multimorbidity clusters in patients with chronic obstructive airway diseases in the EpiChron Cohort. Sci. Rep. 2021, 11, 4784. [CrossRef]

41. Westney, G.; Foreman, M.G.; Xu, J.; King, M.H.; Flenaugh, E.; Rust, G. Peer Reviewed: Impact of Comorbidities Among Medicaid Enrollees With Chronic Obstructive Pulmonary Disease, United States, 2009. Prevent. Chron. Dis. 2017, 14, 160333. [CrossRef]

42. Winhusen, T.; Theobald, J.; Kaelber, D.C.; Lewis, D. Regular cannabis use, with and without tobacco co-use, is associated with respiratory disease. Drug Alcohol Depend. 2019, 204, 107557. [CrossRef] [PubMed]

43. Abuse, S.; Administration, M.H.S. National Survey on Drug Use and Health: Sample Redesign Issues and Methodological Studies. Available online: https:/ / pubmed.ncbi.nlm.nih.gov/30299635/ (accessed on 1 November 2021).

44. Kessler, R.C.; Andrews, G.; Colpe, L.J.; Hiripi, E.; Mroczek, D.K.; Normand, S.-L.; Walters, E.E.; Zaslavsky, A.M. Short screening scales to monitor population prevalences and trends in non-specific psychological distress. Psychol. Med. 2002, 32, 959-976. [CrossRef] [PubMed]

45. Tsuji, T.; Aoshiba, K.; Nagai, A. Cigarette smoke induces senescence in alveolar epithelial cells. Am. J. Respir. Cell Mol. Biol. 2004, 31, 643-649. [CrossRef]

46. Schivo, M.; Avdalovic, M.V.; Murin, S. Non-cigarette tobacco and the lung. Clin. Rev. Allergy Immunol. 2014, 46, 34-53. [CrossRef]

47. Boffetta, P.; Hecht, S.; Gray, N.; Gupta, P.; Straif, K. Smokeless tobacco and cancer. Lancet Oncol. 2008, 9, 667-675. [CrossRef]

48. Pednekar, M.S.; Gupta, P.C.; Yeole, B.B.; Hébert, J.R. Association of tobacco habits, including bidi smoking, with overall and site-specific cancer incidence: Results from the Mumbai cohort study. Cancer Causes Control 2011, 22, 859-868. [CrossRef]

49. Mejia, A.B.; Ling, P.M.; Glantz, S.A. Quantifying the effects of promoting smokeless tobacco as a harm reduction strategy in the USA. Tobac. Control 2010, 19, 297-305. [CrossRef]

50. Farris, S.G.; Leyro, T.M.; Allan, N.P.; Øverup, C.S.; Schmidt, N.B.; Zvolensky, M.J. Distress intolerance during smoking cessation treatment. Behav. Res. Ther. 2016, 85, 33-42. [CrossRef]

51. Bae, Y. Chaotic dynamics in tobacco's addiction model. Int. J. Fuzzy Logic Intell. Syst. 2014, 14, 322-331. [CrossRef]

52. Eklund, B.-M.; Nilsson, S.; Hedman, L.; Lindberg, I. Why do smokers diagnosed with COPD not quit smoking?-a qualitative study. Tobac. Ind. Dis. 2012, 10, 17. [CrossRef]

53. Vogt, F.; Hall, S.; Marteau, T.M. Examining why smokers do not want behavioral support with stopping smoking. Patient Educ. Counsel. 2010, 79, 160-166. [CrossRef] [PubMed]

54. Wilson, J.S.; Elborn, J.S.; Fitzsimons, D. 'It's not worth stopping now': Why do smokers with chronic obstructive pulmonary disease continue to smoke? A qualitative study. J. Clin. Nurs. 2011, 20, 819-827. [CrossRef]

55. Singh, G.; Zhang, W.; Kuo, Y.-F.; Sharma, G. Association of psychological disorders with 30-day readmission rates in patients with COPD. Chest 2016, 149, 905-915. [CrossRef] [PubMed] 
56. MacMurdo, M.; Lopez, R.; Udeh, B.L.; Zein, J.G. Alcohol use disorder and healthcare utilization in patients with chronic asthma and obstructive lung disease. Alcohol 2021, 93, 11-16. [CrossRef]

57. Leung, K.S.; Parks, J.; Topolski, J. Preventable hospitalizations among adult Medicaid beneficiaries with concurrent substance use disorders. Prevent. Med. Rep. 2015, 2, 379-384. [CrossRef] [PubMed] 